\title{
ADAPTATION MEASURES BY CROP FARMERS IN THE SOUTHEAST RAINFOREST ZONE OF NIGERIA TO CLIMATE CHANGE
}

\author{
ONYENEKE, R. U11. \& *MADUKWE, D. K². \\ 1Department of Agricultural Economics, Extension and Rural \\ Development, Imo State University Owerri, Nigeria \\ 2Department of Crop Science and Biotechnology, Imo State \\ University Owerri, Nigeria \\ *donkele2002@yahoo.com
}

\section{INTRODUCTION}

The United Nations Framework Convention on Climate Change (UNFCCC) defines climate change as: "a change of climate which is attributed directly or indirectly to human activity that alters the composition of the global and/or regional atmosphere and which is in addition to natural climate variability observed over comparable time periods". In other words, the UNFCCC uses the term climate change to mean only those changes that are brought about by human activities. In recent usage, the term "climate change" often refers to changes in modern climate which according to the IPCC (2007) are 90-95 percent likely to have been in part caused by human action. Climate changes reflect variations within the earth's atmosphere, processes in other parts of the earth such as oceans, and the effects of human activity (Miller \& Edwards, 2001).

Broad scientific agreement now exists that continued accumulation of heat-trapping "greenhouse" gases in the atmosphere is contributing to changes in the global climate, and in the climates of regions around the world (Crosson, 1997). It is known that subSaharan Africa is a marginal contributor of global climate change but it is the region that is mostly affected by climate change. Climate is an important resource to crop production in Nigeria especially in the rainforest zone of Nigeria as farmers depend largely on rainfed agriculture (Onyeneke, 2010). The key point therefore is how farmers in the zone respond to climate change through their farming activities.

Studies indicate that Africa's agriculture is negatively affected by climate change (Pearce et al., 1996; McCarthy et al., 2001; Onyeneke, 2010) and that adaptation is one of the policy options for reducing the negative impact of climate change (Adger et al., 2003; Kurukulasuriya \& Mendelsohn, 2006). Adaptation to climate change refers to adjustment in natural or human systems in response to actual or expected climatic stimuli or their effects, which moderates harm or exploits beneficial opportunities (IPCC,

2001). Common adaptation methods in agriculture include use of new crop varieties and livestock species that are better suited to drier conditions, irrigation, crop diversification, adoption of mixed crop and livestock farming systems, and changing planting dates (Bradshaw et al., 2004; Kurukulasuriya \& Mendelsohn ,2006; Nhemachena \& Hassan 2007; Onyeneke, 2010).

Few attempts have been made to study farm level adaptation methods in the rainforest zones of Africa (NMSA, 2001; Nhemachena \& Hassan, 2007; Deressa, 2007; Nwajiuba et al., 2008; Deressa et al., 2008; Yesuf et al., 2008; Gbetibouo, 2009). Of these studies, only Deressa et al. (2008) and Yesuf et al. (2008) in Ethiopia attempted to determine the barriers to adaptation to climate change in the rainforest zone. This has left a void in research. Filling this gap is the objective of this paper.
Study Area: The study was carried out in Imo and Abia States located within the Southeast Rainforest Zone of Nigeria. The zone is located on latitudes $5^{0} 06^{\prime} \mathrm{N}$ to $64^{0} 4^{\prime} \mathrm{N}$ of the Equator and

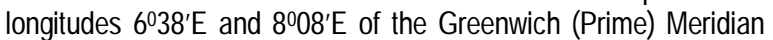
(Microsoft Corporation, 2009). Imo and Abia States were selected from the zone for this study because of proximity, familiarity, and cost. The States have three agricultural zones each Orlu, Owerri, and Okigwe agricultural zones for Imo State and Bende, Aba, and Umuahia agricultural zones for Abia State. These divisions are for administrative and extension services and not for any agroecological difference.

The six agricultural zones were selected for the cross sectional survey of the study. In each of the six zones, one Local Government Area (LGA) was randomly selected from which two communities were selected at random, making a total of twelve communities. In each community, five crop farmers available and willing to respond to questions during the time of the survey were interviewed, bringing the number of respondents for the cross sectional survey to sixty. The main tool for data collection was the questionnaire. Data collected were analyzed using descriptive statistics.

Farmers' Adaptation to Climate Change: The adaptation measures for this study are based on asking crop farmers about their perception to climate change and the actions they take to counteract the negative impacts of climate change. The adaptation measures that farmers report may be profit driven, rather than climate change driven. Despite this missing link, we assume that their actions are driven by climatic factors, as reported by farmers themselves (Maddison, 2006; Nhemachena \& Hassan, 2007). From the responses, the researchers delineated seven broad categories of adaptation to climate change.

Portfolio Diversification: Specific categories encapsulated in this option are using improved crop varieties, intercropping, and using different crop varieties that survive in adverse climatic conditions.

Soil Conservation: Farmers' specific adaptation options listed in this category include mulching, planting of cover crops, applying fertilizer and organic manure.

Changing Planting Dates: This covers early planting and late planting options.

Changing Tillage Operations: The options in this category are using minimum tillage operations, full tillage operation and digging ridges across slopes in the farm against erosion.

Planting Trees: This specifically involves planting trees in the farm to serve as shade against harsh temperature.

Irrigation: As the name implies, it involves supplying water to the farm. The informal type is used here.

No Adaptation: This term was designed to accommodate the category of farmers who did not use any adaptation method to counteract the negative impact of climate change. 
Table 1 reveals that portfolio diversification was the most commonly used method by the farmers $(20.0 \%)$ while the use of irrigation was the least practised adaptation methods identified (3.3\%). Moreover, $43.3 \%$ of the surveyed farmers reported not to have taken any adaptation method.

\section{TABLE 1. DISTRIBUTION OF THE ADAPTATION METHODS OF THE FARMERS}

\begin{tabular}{lcc}
\hline Adaptation & Frequency & Percentage \\
\hline No Adaptation & 26 & 43.3 \\
Portfolio Diversification & 12 & 20.0 \\
Soil Conservation & 9 & 15.0 \\
Changing Planting Dates & 7 & 11.7 \\
Planting Trees & 6 & 10.0 \\
Changing Tillage & 4 & 6.7 \\
Operations & 2 & 33.3 \\
Irrigation & 2 & \\
\hline
\end{tabular}

Barriers to Adaptation to Climate Change: The analysis of barriers to adaptation to climate change in the Southeast Rainforest Zone of Nigeria indicates that there are five major constraints to adaptation. These are lack of information on appropriate adaptation option confirmed by $50.00 \%$ (majority) of the farmers, lack of finance cited by $35.00 \%$ of the farmers, shortage of labour reported by $15.00 \%$ of the farmers, shortage of land confirmed by $5.00 \%$ of the farmers, and poor access to market agreed by $5.00 \%$ of the farmers (Fig. 1)

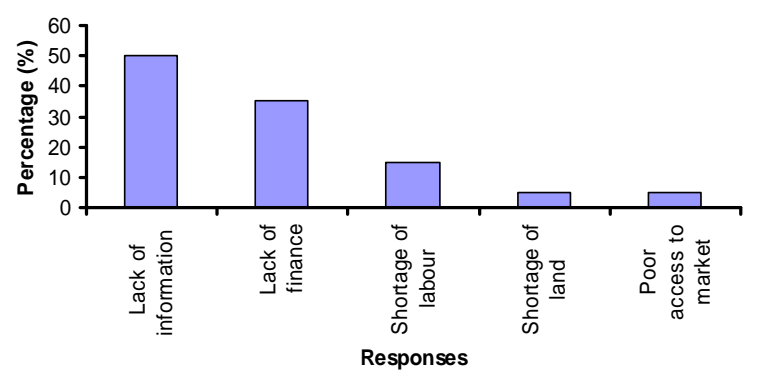

FIG. 1. BARRIERS TO ADAPTATION

Greater adoption of portfolio diversification as an adaptation method could be associated with the lower expense and ease of access by farmers, while the limited use of irrigation could be attributed to the need for more capital and low potential for irrigation. The reason for the greater proportion of the surveyed farmers not choosing any adaptation option is as a result of certain constraints associated with lack of information and poverty. For instance, lack of information on appropriate adaptation options could be attributed to the dearth of research on climate change and adaptation options in the country. Lack of finance hinders farmers from getting the necessary resources and technologies that facilitate adapting to climate change. Adaptation to climate change is costly (Deressa et al., 2008), and the need for intensive labour use may contribute to this cost. Thus, if farmers do not have sufficient family labour or the financial means to hire labour, they cannot adapt. Shortage of land has been associated with high population pressure, which forces farmers to intensively farm a small plot of land and makes them unable to prevent further damage by using practices, such as continuous and multiple cropping that compete for agricultural land. Poor access to market entails poor link to input and output markets, and this hinders farmers' adaptation to climate change.

The farmers in the rainforest of the areas studied adapt in various ways to climate change. More than half of the number of farmers studied has taken steps to adjust their farming activities.
The common adaptation practices used by farmers in the southeast rainforest zone of Nigeria are portfolio diversification and soil conservation practices. Very few proportion of the farmers use irrigation to adapt to perceived changes in climatic variables. The limited use of irrigation in the zone could be attributed to its capital intensive requirements, low potential for irrigation and the total dependence on rainfed agriculture. The main barriers to adaptation to climate change are lack of information on appropriate adaptation option, lack of finance, and shortage of farm labour.

In terms of the effect of this work on policy change of the government, it is suggested that government should ensure that farmers have access to affordable credit and land to increase their ability and flexibility to change production strategies in response to climate change. Government should also ensure that extension services of the Ministry of Agriculture reach the resource poor farmers in rural areas, particularly information and other packages that will help them adjust and readjust to climate change. It must be emphasized that while most agricultural adaptation response to climatic event and climate change will ultimately be characterized by responses at the local level, the encouragement of responses by government at the national level will affect the speed and extent of adaptation. Thus, federal government should encourage research, training and communications among farmers, extension practitioners and research institutes concerning the most appropriate adaptive options. It is also significant to note that selecting preferred strategies will almost always involve trade-offs between meeting different objectives.

The analysis of adaptation methods to climate change and its barriers suggest a number of policy options that raising awareness of climate change and the appropriate adaptation methods, facilitating the availability of credit, investing in yield-increasing technology packages to increase farm income, creating opportunities for off-farm employment, conducting research on use of new crop varieties and livestock species that are better suited to drier and wetter conditions, encouraging informal social networks, and investing in irrigation.

\section{REFERENCES}

Adger, W. N.; Huq, S.; Brown, K.; Conway, D. and Hulme M. (2003). Adaptation to Climate Change in the Developing World. Progress in Development Studies No. 3.

Bradshaw, B.; Dolan H. and Smith B. (2004). Farm-level adaptation to Climatic Variability and Change: Crop Diversification in the Canadian Prairies. Climatic Change Vol. 67.

Crosson, P. (1997). Impacts of Climate Change on Agriculture. Climate Issues Brief No.4. Washington D.C., Resources for the Future.

Deressa, T. (2007). Measuring the Economic Impact of Climate Change on Ethiopian Agriculture: Ricardian Approach. World Bank Policy Research Paper No. 4342. Washington D.C.: World Bank.

Deressa, T.; Hassan, R.M.; Alemu, T.; Yesuf, M. and Ringler, C. (2008). Analyzing the Determinants of Farmers' Choice of Adaptation Methods and Perceptions of Climate Change in the Nile Basin of Ethiopia. International Food Policy Research Institute (IFPRI) Discussion Paper No. 00798. Environment and Production Technology Division, IFPRI, Washington D.C.

Gbetibouo, G. A. (2009). Understanding Farmers' Perception and Adaptations to Climate Change and Variability: The Case of the Limpopo Basin, South Africa. International Food Policy Research Institute (IFPRI) Discussion Paper 00849, February, 2009. Environment and Production Technology Division, IFPRI 
IPCC (2001). Climate Change 2001: Impacts, Vulnerability and Adaptation. Contribution of Working Group III to the Third Assessment Report on the Intergovernmental Panel on Climate Change. Cambridge University Press, Cambridge.

IPCC (2007). Climate Change 2007: The Physical Science Basis (Summary for Policy), IPCC, Geneva.

Kurukulasuriya, P. and Mendelsohn, R. (2006). A Ricardian Analysis of the Impact of Climate Change on African Crop Land. CEEPA Discussion Paper No. 8. Centre for Environmental Economics and Policy in Africa. Pretoria, South Africa: University of Pretoria.

Maddison, D. (2006). The Perception of and Adaptation to Climate Change in Africa. CEEPA. Discussion Paper No. 10. Centre for Environmental Economics and Policy in Africa. Pretoria, South Africa: University of Pretoria.

McCarthy, J.; Canziani, O.F.; Leary, N.A.; Dokken, D.J. and C.,White (2001). Climate change 2001: Impacts, Adaptation, and Vulnerability. Contribution of Working Group II to the Third Assessment Report of the Intergovernmental Panel on Climate Change. Cambridge: Cambridge University Press.

Microsoft Corporation (2009): Microsoft Encarta Premium Suite 2009 (Software).

Miller, C. and Edwards, P.N. (2001). Changing the Atmospheric Expert Knowledge and Environmental Governance, MIT Press, Massachusett.

Nhemachena, C. and Hassan, R. (2007). Micro-level Analysis of Farmers' Adaptation to Climate Change in Southern Africa. International Food Policy Research Institute (IFPRI) Discussion Paper No. 00714. Environment and Production Technology Division, IFPRI, Washington, D.C.
NMSA (National Meteorological Services Agency) (2001). Initial National Communication of Ethiopia to the United Nations Framework Convention on Climate Change (UNFCCC), Addis Ababa, Ethiopia

Nwajiuba, C.U.; Onyeneke, R. and Munonye, J. (2008). Climate Change: Perception and Adaptation by Poultry Farmers in Imo State. In: Nwajiuba C. (ed), Climate Change and Adaptation in

Nigeria. Farming and Rural Systems Economics by Doppler W. and Bauer S., Volume 95, Margraf Publishers, Hohenheim, Germany.

Onyeneke, R. U. (2010). Climate Change and Crop Farmers' Adaptation Measures in the Southeast Rainforest Zone of Nigeria. Unpublished M.Sc. Thesis submitted to the Department of Agricultural Economics, Imo State University Owerri, Nigeria, 112 pp.

Pearce, D; Cline, W.; Achanta, A.; Fankhauser, S.; Pachauri, R.; Tol, R. and Vellinga, P. (1996). The Social Costs of Climate Change: Greenhouse Damage and Benefits of Control. In Climate change 1995: Economic and Social Dimensions of Climate Change, ed. J. Bruce, H. Lee, and E. Haites. Cambridge: Cambridge University Press.

Yesuf, M.; Difalce, S.; Deressa, T.; Ringler, C. and Kohlin, G. (2008). The Impact of Climate Change and Adaptation on Food Production in Low-Income Countries: Evidence from the Nile Basin, Ethiopia, International Food Policy Research Institute Discussion (IFPRI) Paper No. 00828. Environment and Production Technology Division, IFPRI, Washington D.C. 